\title{
Students Expectations using Opinion Mining Clustering
}

\author{
Monika Gupta Vashisht, Bhawna, Ashima Kalra
}

\begin{abstract}
Students and their parents have become more and more aware of the importance of gaining higher education in India. Government of India, as well as state governments, has been framing various policies to promote higher education in various fields such as engineering, management, and hotel management, medical and allied disciplines. An attempt has been made to analyze the expectations of students pursuing higher education in the state of Punjab and Haryana in India. For this, Clustering approach has been used. Students studying in selected engineering colleges have been approached. Two clusters have been evolved: Career-Oriented Students and Society Conscious Students. This research gives further directions for the future as the same can be conducted in other institutes and in other cities, states, and countries too.
\end{abstract}

Index Terms: Students, Higher Education, Engineering, Career, Social, Fun, Clustering Analysis.

\section{INTRODUCTION}

The largest higher education system in the world is in India and student enrolment in higher education provides India second rank with the enrollment of 36.64 million students in higher education in 2017-18 (IBEF, April 2019). Importance of higher education has been realized throughout the world besides the preliminary requirement of basic education. As a result, campus placement is becoming competitive and role of quality faculty is realized (H. Malini and L. Suresh, 2018). H. Afzal, I. Ali, M. A. Khan and K. Hamid (2010) also emphasized the role of best teachers, bright students and best schooling in academic performance, motivation, and accomplishment of students. For performance analysis and gap identification, the feedback has been considered as an important factor in educational institutions (A. Chitriv and A. Thomas, 2018). One application of data mining is Educational data mining with student and faculty as two key domains (P. Ughade and S.W. Mohod, 2016).

\section{A. Basic Terminology}

A Cluster refers to a group of similar kind of objects.

Hierarchical Clustering Method creates a hierarchical disintegration of data objects in the given set.

Students' satisfaction with a course and their willingness to engage in certain activities will depend in part on how well the instructor's definition of what is happening in the classroom aligns with their own (Augusta University), Objective of the study

Revised Manuscript Received on June 15, 2019.

Dr. Monika Gupta Vashisht, CBSA, CGC Landran, India.

Dr. Bhawna, CEC, CGC Landran India.

Ms. Ashima Kalra, CEC, CGC Landran India.
The objective of the study undertaken is:

- “To determine how students' expectations rate on professional institute evaluation for better higher education environment".

\section{PROCEDURE FOR PAPER SUBMISSION REVIEW OF LITERATURE}

Atta-Ur-Rahman, K. Sultan, N. Aldhafferi and A. Alqahtani (2018) aimed to discover the trend of the comfort level of students with respect to timetabling and teaching techniques. H. Kaur and G. Bathla (2018) briefly described the data mining techniques. The literature review of educational data mining is also done. This paper, implemented data mining techniques such as Naive Bayes and Support vector machine to predict the student performance. V. Dahiya (2018) presented a survey on various components of educational data mining along with its objectives.

\section{RESEARCH METHODOGY}

The study undertaken is focused on analyzing college student expectations. The questions related to respondents' demographics were based on research conducted by H. Afzal, I. Ali, M. A. Khan and K. Hamid (2010). The instrument was designed using "The University Student Motivation and Satisfaction Questionnaire version 2". (TUSMSQ2) instrument developed by Neill (2004) to measure student's motivation contains 30 -items.

Closed Items - Final Format Student Motivation

\section{I attend university...}

1 because I don't know what else to do.

2 to understand myself better.

3 to gain valuable skills for my career.

4 because its fun place to be.

5 because others expect me to get a degree.

6 because I genuinely want to help others.

7 because it's a better alternative than working.

8 because I want to explore new ideas.

9 to enhance my job prospects.

10 because I enjoy the social life. 


\begin{tabular}{|c|c|}
\hline 11 & because other people have told me I should. \\
\hline 12 & because I want to contribute to society. \\
\hline 13 & to avoid being unemployed. \\
\hline 14 & because I want to challenge myself. \\
\hline 15 & in order to get the qualification. \\
\hline 16 & because I enjoy the social environment. \\
\hline 17 & $\begin{array}{l}\text { because it would disappoint other people if I } \\
\text { didn't. }\end{array}$ \\
\hline 18 & $\begin{array}{l}\text { because I want to help solve society's } \\
\text { problems. }\end{array}$ \\
\hline 19 & because it gives me something to do. \\
\hline 20 & for my personal growth and development. \\
\hline 21 & because it will help set up my future career. \\
\hline 22 & because of the social opportunities. \\
\hline 23 & it seems to be the recommended thing to do. \\
\hline 24 & $\begin{array}{l}\text { because I want to improve the world } \\
\text { situation. }\end{array}$ \\
\hline 25 & because I don't have any better options. \\
\hline 26 & because I love learning. \\
\hline 27 & so I can get a better job. \\
\hline 28 & $\begin{array}{l}\text { because its a great place to develop } \\
\text { friendships. }\end{array}$ \\
\hline 29 & of social expectations from those around me. \\
\hline 30 & because I want to be more useful to society. \\
\hline
\end{tabular}

The survey included the following sections:

- Questions related to student demographics- Year of Study, and Programme of Study;

- 30 items to measure the motivations of college students to be a part of the college.

For data collection, relative to student expectations, the respondents were asked to indicate their degree of agreement or disagreement with each statement. The attribute items were measured on a 5-point Likert type scale of importance with 5 beings 'Strongly Agree' to 1 being 'Strongly Disagree'.

-Sampling Design: The Universe of the study comprised all adult farmers (above 18 years of age) residing in India. The Survey (Target) Population included all students pursuing higher education in the Sahibzada Ajit Singh Nagar (Mohali) District, Punjab State, India. The students who were willing to respond to the questionnaire could be contacted either at their place of study on working days during the semester or at their residence.

The sampling design employed was non-probability judgment and convenience sampling. 150 respondents comprised the final sample.

-Sample: The students pursuing higher education.

- Demographics: Year of Study, and Programme of Study.

\begin{tabular}{|c|c|c|}
\hline Descriptive & Frequency & Percentage \\
\hline \multicolumn{3}{|l|}{ Programme of Study } \\
\hline Business Management (BM) & 47 & 31 \\
\hline Engineering (EN) & 50 & 33 \\
\hline Hotel Management (HM) & 36 & 24 \\
\hline Education (ED) & 17 & 12 \\
\hline Total & 150 & \\
\hline \multicolumn{3}{|l|}{ Year of Study } \\
\hline First Year $(\mathrm{BM})$ & 17 & 11 \\
\hline First Year (EN) & 2 & 1 \\
\hline First Year (HM) & 2 & 1 \\
\hline First Year (ED) & 5 & 3 \\
\hline Second Year (EN) & 6 & 4 \\
\hline Second Year (HM) & 4 & 3 \\
\hline Third Year (EN) & 12 & 8 \\
\hline Third Year (HM) & 8 & 6 \\
\hline Final Year (BM) & 30 & 20 \\
\hline Final Year (ED) & 12 & 8 \\
\hline Final Year (EN) & 30 & 20 \\
\hline Final Year (HM) & 22 & 15 \\
\hline Total & 150 & \\
\hline \multicolumn{3}{|l|}{ Gender } \\
\hline Male (BM) & 25 & 17 \\
\hline Male (EN) & 34 & 22 \\
\hline Male (HM) & 22 & 15 \\
\hline Male (ED) & 14 & 10 \\
\hline Female (BM) & 22 & 15 \\
\hline Female (EN) & 16 & 10 \\
\hline Female (HM) & 14 & 9 \\
\hline Female (ED) & 3 & 2 \\
\hline Total & 150 & \\
\hline
\end{tabular}

The combined sample consisted of one-third (33\%) of the respondents pursuing engineering, another one-third (31\%), pursuing business management, whereas other $24 \%$ were pursuing hotel management and remaining $11 \%$ were enrolled in department of education. Of the students surveyed, nearly two-third were studying in final year $(63 \%)$ and remaining one-third collectively in first $(16 \%)$, third $(14 \%)$ and second year $(7 \%)$. Majority of the respondents were male $(64 \%)$ and remaining were females $(36 \%)$.

In summary the typical sample respondent profile can be described as follows:

The respondents were mainly male students pursuing final year in 
engineering and management programmes.

\section{STATISTICAL ANALYSIS}

The study tested statistically the students' motives for educational institutes. The statistical significance was set at a level of 0.05 .

Results and Findings of the Study

SPSS Statistics, 16.0.1 version, was used for performing Cluster Analysis. A new student typology, named as Career-Oriented Students and Society-Conscious Students, has been evolved. Higher education Professional Institute scenario based on profiling of students types was created. Profiling of students clusters based on students' expectations was done. A significant association between expectations and education motives was checked using the Pearson Correlation Coefficient. This indicates that educational motivation is directly proportional to student expectation.

The next stage of profiling included demographics and motive of receiving education variables. For cross-tabulating the data, a Chi-Square Test has been administered in order to profile the two segments. The statistically significant differences were found (Refer to Table 2).

Table 2: Frequencies of Students Pursuing Higher Education

\begin{tabular}{llll}
\hline Descriptive & $\begin{array}{l}\text { Career } \\
\text { Oriented } \\
\text { Students } \\
\text { (Cluster I) }\end{array}$ & $\begin{array}{l}\text { Society } \\
\text { Conscious } \\
\text { Students } \\
\text { (Cluster II) }\end{array}$ & $\begin{array}{l}\text { Total } \\
\text { Sample } \\
\text { Frequency }\end{array}$ \\
\hline $\begin{array}{l}\text { Programme } \\
\text { Business }\end{array}$ & 28 & 19 & 47 \\
$\begin{array}{l}\text { Management } \\
\text { Engineering }\end{array}$ & 44 & 6 & 50 \\
$\begin{array}{l}\text { Hotel } \\
\text { Management }\end{array}$ & 29 & 7 & 36 \\
$\begin{array}{l}\text { Education } \\
\text { Total }\end{array}$ & 17 & 0 & 17 \\
\hline
\end{tabular}

Table 3 Programme of Study* Students Clusters

\begin{tabular}{|c|c|c|c|c|c|}
\hline \multicolumn{6}{|c|}{ Programme * Cluster Crosstabulation } \\
\hline & & & \multicolumn{2}{|l|}{ Cluster } & \multirow[t]{2}{*}{ Total } \\
\hline & & & 1.00 & 2.00 & \\
\hline \multirow[t]{10}{*}{ Year } & \multirow{5}{*}{$\begin{array}{l}1.0 \\
0\end{array}$} & Count & 28 & 19 & 47 \\
\hline & & $\begin{array}{l}\text { Expected } \\
\text { Count }\end{array}$ & 37.0 & 10.0 & 47.0 \\
\hline & & $\begin{array}{ll}\% & \text { within } \\
\text { Year } & \end{array}$ & $59.6 \%$ & $40.4 \%$ & $\begin{array}{l}100.0 \\
\%\end{array}$ \\
\hline & & $\begin{array}{l}\% \text { within } \\
\text { Cluster }\end{array}$ & $23.7 \%$ & $59.4 \%$ & $31.3 \%$ \\
\hline & & $\%$ of Total & $18.7 \%$ & $12.7 \%$ & $31.3 \%$ \\
\hline & \multirow{5}{*}{$\begin{array}{l}2.0 \\
0\end{array}$} & Count & 44 & 6 & 50 \\
\hline & & $\begin{array}{l}\text { Expected } \\
\text { Count }\end{array}$ & 39.3 & 10.7 & 50.0 \\
\hline & & $\begin{array}{ll}\% & \text { within } \\
\text { Year } & \\
\end{array}$ & $88.0 \%$ & $12.0 \%$ & $\begin{array}{l}100.0 \\
\%\end{array}$ \\
\hline & & $\begin{array}{l}\% \text { within } \\
\text { Cluster }\end{array}$ & $37.3 \%$ & $18.8 \%$ & $33.3 \%$ \\
\hline & & $\%$ of Total & $29.3 \%$ & $4.0 \%$ & $33.3 \%$ \\
\hline
\end{tabular}

\begin{tabular}{|c|c|c|c|}
\hline Count & 29 & 7 & 36 \\
\hline $\begin{array}{l}\text { Expected } \\
\text { Count }\end{array}$ & 28.3 & 7.7 & 36.0 \\
\hline $\begin{array}{l}\% \text { within } \\
\text { Year }\end{array}$ & $80.6 \%$ & $19.4 \%$ & $\begin{array}{l}100.0 \\
\%\end{array}$ \\
\hline $\begin{array}{l}\% \text { within } \\
\text { Cluster }\end{array}$ & $24.6 \%$ & $21.9 \%$ & $24.0 \%$ \\
\hline$\%$ of Total & $19.3 \%$ & $4.7 \%$ & $24.0 \%$ \\
\hline Count & 17 & 0 & 17 \\
\hline $\begin{array}{l}\text { Expected } \\
\text { Count }\end{array}$ & 13.4 & 3.6 & 17.0 \\
\hline $\begin{array}{l}\% \text { within } \\
\text { Year }\end{array}$ & $\begin{array}{l}100.0 \\
\% \\
\end{array}$ & $0.0 \%$ & $\begin{array}{l}100.0 \\
\% \\
\end{array}$ \\
\hline $\begin{array}{l}\% \text { within } \\
\text { Cluster }\end{array}$ & $14.4 \%$ & $0.0 \%$ & $11.3 \%$ \\
\hline$\%$ of Total & $11.3 \%$ & $0.0 \%$ & $11.3 \%$ \\
\hline Count & 118 & 32 & 150 \\
\hline $\begin{array}{l}\text { Expected } \\
\text { Count }\end{array}$ & 118.0 & 32.0 & 150.0 \\
\hline $\begin{array}{l}\% \text { within } \\
\text { Year }\end{array}$ & $78.7 \%$ & $21.3 \%$ & $\begin{array}{l}100.0 \\
\%\end{array}$ \\
\hline $\begin{array}{l}\% \text { within } \\
\text { Cluster }\end{array}$ & $\begin{array}{l}100.0 \\
\%\end{array}$ & $\begin{array}{l}100.0 \\
\%\end{array}$ & $\begin{array}{l}100.0 \\
\%\end{array}$ \\
\hline$\%$ of Total & $78.7 \%$ & $21.3 \%$ & $\begin{array}{l}100.0 \\
\%\end{array}$ \\
\hline
\end{tabular}

Programme of Study: 1-Business Management, 2-Engineering, 3-Hotel Management, 4- Education; Cluster 1: Career-Oriented Students, 2: Society-Conscious Students

Result of the Chi-Square Test: There is significant relationship between Programmes and Student Motivation and Satisfaction -based clusters $\left(\chi_{\text {cal }}^{2}=17.491, \chi_{t a b}^{2}\right.$ $=19.920, d f=3$, $p$-value $=0.001$ )

Summary of Results of Chi-Square Tests of Independence on Student's Clusters

In summary, we can say that there is a statistically significant relationship between the higher education motives-based clusters (Career Oriented Students and Society Conscious Students) and the select demographic variable: Programme of Study.

\section{DISCUSSIONS}

- Students pursuing engineering and management are more career conscious than those pursuing hotel management and 'Education'.

Career Oriented Students and Society Conscious Students

Table 4: Segmentation Profiles of Students' Clusters 


\begin{tabular}{|c|c|c|}
\hline Characteristics & $\begin{array}{l}\text { Career Oriented } \\
\text { Students }\end{array}$ & $\begin{array}{l}\text { Society } \\
\text { Conscious } \\
\text { Students }\end{array}$ \\
\hline \multirow{2}{*}{$\begin{array}{l}\text { Higher } \\
\text { Education } \\
\text { motives }\end{array}$} & Focused & Unfocused \\
\hline & $\begin{array}{l}\text { Gaining Higher } \\
\text { Education }\end{array}$ & $\begin{array}{l}\text { Gaining Higher } \\
\text { Education }\end{array}$ \\
\hline \multirow[t]{9}{*}{ Occupation } & $18.7 \% \quad$ Business & $12.7 \% \quad$ Business \\
\hline & Management & Management \\
\hline & $29.3 \%$ & $4.0 \%$ Engineering \\
\hline & Engineering & \\
\hline & 19.3\% Hotel & $4.7 \% \quad$ Hotel \\
\hline & Management & Management \\
\hline & $11.3 \%$ Education & $0.0 \%$ Education \\
\hline & $60.0 \%$ Others & $40.0 \%$ Others \\
\hline & $61.9 \%$ Retired & $38.1 \%$ Retired \\
\hline
\end{tabular}

\section{Professional Institute Strategies for Creating Better} Higher Education Environment among Students:

Despite various institute patronizing motives and education values, a pleasing educational atmosphere is expected to enhance perceptions of education service quality, and foster students' approach behaviour.

\section{CONCLUSION}

It has been observed that many higher education institutes offering similar programmes are likely to come up and there will be stiff competition in the near future. Therefore, managing an institute offering professional higher education will be more challenging. Management needs to understand the changing mindset of the students and deliver quality services catering to the needs and expectations of students seeking admission to various programmes. Educational institutes not only cater to the career-oriented needs of the students but also focusing on the all-round development of students. It is high time that management needs to come up with a USP to create visibility in the educational institute to get the desired response from the prospects. The respondents include rural youth 18 years of age and above, the behavior of residents below 18 years may exhibit different behavior. The study covered only the respondents Iindulged in farming, remaining youth may exhibit different behaviour. The exploratory study was conducted in Mohali, Punjab, India; the farmers' perceptions and attitude might vary in other regions. The findings of the first objective of the study provide the basis for further research to be carried out in the same field with larger sample size, larger area, might be expanded across the boundaries, or could be applied to universities.

\section{REFERENCES}

1. A. Dutt, M.A. Ismail and T. Herawan, "A systematic review on educational data mining," IEEE Access, ResearchGate, vol. 5, pp. 15991-16005, 2017.

2. S. Kausar, X. Huahu, I. Hussain, Z. Wenhao, and M. Zahid, "Integration of data mining clustering approach in the personalized E-Learning system," IEEE Access, vol. 6, pp. 72724-34, 2018.

3. I. Majeed, "Current State of Art of Academic Data Mining and Future Vision," Indian Journal of Computer Science and Engineering, vol. 9(2), pp. 49-56, April-May 2018.

4. K. J. G. Leeuwenkamp, D. J. Brinke and L. Kester, "Developing questionnaires to measure students' expectations and perceptions of assessment quality," Cogent Education, vol. 5, pp. 1-16, 2018.
5. J. Chang K. Choi, K. K. Moon, P. Chan, T. LK. Chan and C. To, "Teaching practices: a cluster analysis of students in Hong Kong," Developments in Business Simulations and Experiential Learning, vol. 32, pp. 373-80, 2005.

6. C. Singh and A. Gopal, "Performance analysis of faculty using data mining techniques," International Journal of Computer Science and Application, pp. 140-144, 2010.

7. H. Afzal, I. Ali, M. A. Khan and K. Hamid, "A study of university students' motivation and its relationship with their academic performance", International Journal of Business and Management, Vol. 5, No. 4, pp. 80-88, April 2010.

8. S. Arumugam, A. Kovalan and A.E. Narayanan, "A study of easy educational data mining for e-learning log data from complex and large dataset," International Journal of Innovations in Engineering and Technology (IJIET), vol. 11(1). Oxford: Clarendon, 1892, pp.39-47, August 2018.

9. Atta-Ur-Rahman, K. Sultan, N. Aldhafferi and A. Alqahtani, "Educational data mining for enhanced teaching and learning," Journal of Theoretical and Applied Information Technology, vol 96(14), pp. 4417-4427, 31st July 2018.

10. P. Ughade and S.W. Mohod, "A survey on analysis of faculty performance using data and opinion mining," International Journal of Innovative Research in Computer and Communication Engineering, vol. 4(1), pp. 87-91, January 2016.

11. A. Chitriv and A. Thomas, "Analysis of student feedback by using data mining techniques," Helix, vol. 8(5), pp. 4034-38, August 2018.

12. H. Kaur and G. Bathla, "Student performance prediction using educational data mining techniques," International Journal on Future Revolution in Computer Science \& Communication Engineering, vol. 4(12), pp. 93-97, 2018.

13. H. Malini and L. Suresh, "Data mining in higher education system and the quality of faculty affecting students academic performance: A systematic review," International Journal of Innovations \& Advancement in Computer Science, vol. 7(3), pp. 66-70, March 2018.

14. V. Dahiya, "A survey on educational data mining," International Journal of Research in Humanities, Arts and Literature, IEEE Access, ResearchGate, vol. 6(5), pp. 23-30, May 2018.

15. E. Popescu and F. Leon, "Predicting academic performance based on learner traces in a social learning environment," IEEE Access, vol. 6, pp. 72774-72785, 2018.

16. "Indian education sector in India industry report", India Brand Equity Foundation (IBEF), April, 2019.

17. https://www.tutorialspoint.com/data_mining/dm_cluster_analysis.ht $\mathrm{m}$

18. Student Expectations, Augusta University, https://www.augusta.edu/student-affairs/professionalism.php Students' Definitions of the College Classroom, Tomorrow's Teaching and Learning, https://tomprof.stanford.edu/posting/1616

19. Teaching Excellence \& Educational Innovation, Course Policies / Expectations, Carnegie Mellon University, Eberly Center, https://www.cmu.edu/teaching/designteach/design/syllabus/samples-p oliciesexpectations/

20. Student Code of Conduct, Cambridge College, September 4, 2018 https://www.cambridgecollege.edu/student-rights-complaints-grievan ces/student-code-conduct

21. M. Gupta and Dr. A. Mittal, "Mall Shopper Clustering in Business Intelligemce", AIMA Journal of Management \& Research, , vol. 6(3/4), pp. 75-95, August 2012.

22. M. Gupta, "Co-Shopper Preference and Mall Shopping- A Study of Delhi and NCR", GGGI Management Review, vol. 4(1), pp. 33-40, January-June, 2014.

23. M. Gupta, "Impact of Shopper's Occupation on Mall Shopping", Journal of IMS Group, vol. 11(1), pp. 49-56, January-June 2014.

24. M. Gupta," Data Mining for Shopping Malls- Customer Loyalty Strategies", Proceedings of National Conference on Advancements in the Era of Multi Disciplinary Systems, Elsevier, a division of Reed Elsevier India Private Limited, India, Chapter 57, pp. 315-320, 2013.

\section{AUTHORS PROFILE}
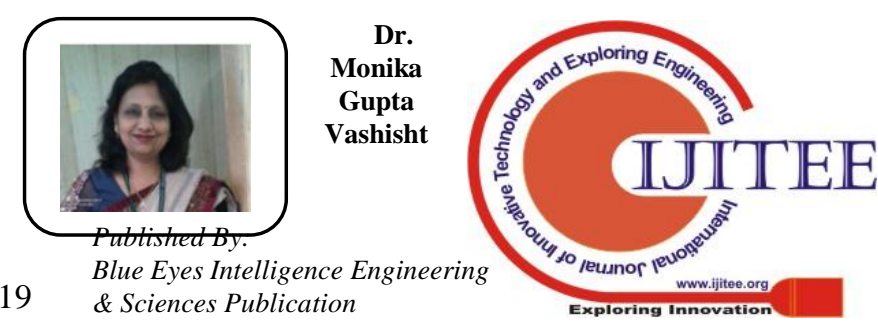
is currently serving as Associate Professor, Chandigarh Business School of Administration, Chandigarh Group of Colleges, Landran-Mohali and has previously served with corporates Nilkamal Group, Amartex Industries Ltd and others for more than 4 years. She has earned Ph.D degree in Management from Maharishi Markandeshwar University, Mullana-Ambala. She is also UGC-NET qualified in Management. She has more than 15 years of academic and corporate experience. Her areas of interest are Marketing Management, Service Marketing, Retail Marketing, Advertising Management, Consumer Behaviour, Strategic Management and Foundations of Management. She has written 21 research papers and 6 book reviews in International and National Journals and Conference Proceedings. She has also organized National Conferences. She is 'Circulation Editor' of UGC listed International Journal 'Biz and Bytes' (Print ISSN: 2320-897X \& E-ISSN: 0976-0458). She also remained 'Editor' of UGC listed International Journal 'GGGI Management Review' (ISSN 2249-4103). She is also 'Associate Editor' of Newletter 'Reflectionz'. She has 'Lifetime Membership' of 'The Society for Management Education' (TSME), Kurukshetra since 2012. Besides, she is coordinating various departmental activities of high responsibility.

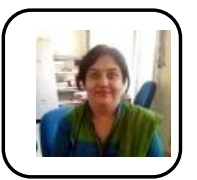

Dr. Bhawna Tandon received her BTech in Electronics and Instrumentation in 2001, ME in Instrumentation and Control in 2009 and $\mathrm{PhD}$ in Control System from Kurukshetra University, Kurukshetra, Panjab University, Chandigarh and PEC (Deemed to be University) Chandigarh respectively. She is having teaching experience of 17 Years and currently working as an Associate Professor at Chandigarh Engineering College, Landran, Mohali. She is having more than 20 research publications in reputed International journals. Her current research interests include robust control, non-linear control and optimisation techniques.

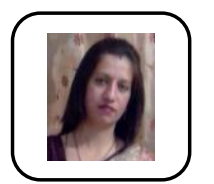

Ashima Kalra , Gold Medalist in B Tech in Electronics from Kurukshetra University, Kurukshetra in 2003 .Received M.Tech degree from Punjab Technical University, Kapurthla (Punjab)in 2008 and pursuing $\mathrm{PhD}$ from Punjab Technical University , Kapurthla (Punjab )in the field of soft Computing. She has published more than 25 papers in reputed journals and 3 book chapters in Springer series. Her research activities include designing model identification using neural networks, fuzzy systems, supervised learning .machine learning. Lifetime IEEE member and has been serving as a fellow member of IEEE Delhi section, India. Organized 3 IEEE international conferences as a chairperson. 